\title{
Characteristics of Future Models of Integrated Outpatient Care
}

\author{
Alan Leviton ${ }^{1, *} \mathbb{C}$, Julia Oppenheimer ${ }^{1}$, Madeline Chiujdea ${ }^{1}$, Annalee Antonetty ${ }^{1}$, \\ Oluwafemi William Ojo ${ }^{1}$, Stephanie Garcia ${ }^{1}$, Sarah Weas ${ }^{2}$, Eric Fleegler ${ }^{3}$, Eugenia Chan ${ }^{2}(1)$ and \\ Tobias Loddenkemper ${ }^{1}$ \\ 1 Division of Epilepsy and Clinical Neurophysiology, Department of Neurology, Boston Children's Hospital \\ and Harvard Medical School, 300 Longwood Avenue, Boston, MA 02115, USA; \\ julia.e.oppenheimer@gmail.com (J.O.); Madeline.Chiujdea@childrens.harvard.edu (M.C.); \\ Annalee.Antonetty@childrens.harvard.edu (A.A.); William.femi@gmail.com (O.W.O.); \\ stephanie.liz.garcia@gmail.com (S.G.); Tobias.Loddenkemper@childrens.harvard.edu (T.L.) \\ 2 Division of Developmental Medicine, Department of Medicine, Boston Children's Hospital and Harvard \\ Medical School, 300 Longwood Avenue, Boston, MA 02115, USA; Sarah.Weas@childrens.harvard.edu (S.W.); \\ Eugenia.Chan@childrens.harvard.edu (E.C.) \\ 3 Division of Emergency Medicine, Department of Medicine, Boston Children's Hospital and Harvard Medical \\ School, 300 Longwood Avenue, Boston, MA 02115, USA; Eric.Fleegler@childrens.harvard.edu \\ * Correspondence: alan.leviton@childrens.harvard.edu; Tel.: +1-617-485-7187
}

Received: 1 April 2019; Accepted: 24 April 2019; Published: 27 April 2019

check for updates

\begin{abstract}
Replacement of fee-for-service with capitation arrangements, forces physicians and institutions to minimize health care costs, while maintaining high-quality care. In this report we described how patients and their families (or caregivers) can work with members of the medical care team to achieve these twin goals of maintaining - and perhaps improving-high-quality care and minimizing costs. We described how increased self-management enables patients and their families/caregivers to provide electronic patient-reported outcomes (i.e., symptoms, events) (ePROs), as frequently as the patient or the medical care team consider appropriate. These capabilities also allow ongoing assessments of physiological measurements/phenomena (mHealth). Remote surveillance of these communications allows longer intervals between (fewer) patient visits to the medical-care team, when this is appropriate, or earlier interventions, when it is appropriate. Systems are now available that alert medical care providers to situations when interventions might be needed.
\end{abstract}

Keywords: consumer health informatics; E-health; mobile apps; outpatient follow-up; patient portal; patient-reported outcomes

\section{Introduction}

The traditional system of medical care is characterized by visits to the clinician who asks about the recent past, examines the patient, makes decisions about therapy, and schedules a follow-up assessment. Between visits, patients often have little contact with their clinical-care team.

The multiple initiatives to encourage innovations in medical-care delivery, which both enhances the quality of care and reduce costs, have allowed a considerable flexibility [1-5]. Here, we offer a ground-level perspective of clinicians and other care providers who are preparing for the soon-to-be reality of outpatient care of children and adults with chronic diseases.

This emerging system of care delivery incorporates greater emphasis on self-management (e.g., consuming medications as prescribed, deciding about the need for medical-care or other adjustments), electronic patient-reported outcomes (i.e., symptoms) (ePROs), the "remote surveillance" system that receives these ePROs and electronic data collected by sensors (e.g., glucometers, activity monitors, 
internet enabled scales), assistance navigating service systems, and alerting programs and algorithms that inform the clinical-care team when additional assessment and intervention might be needed [6]. In this overview, we discuss each of these elements, first individually, and then discuss the systems that integrate them.

\section{Why the Need for the New System?}

The traditional system of periodic outpatient assessments relied on fee-for-service, wasted resources when patients were well (with unnecessary outpatient visits), underutilized resources when care was needed between clinic visits [7], and prompted some patients or their surrogates to delay seeking care for an adverse event, especially outside the bounds of the regular doctors'/clinic hours [8]. In the new system, in keeping with the Affordable Care Act, the fee-for-service model is replaced with capitation arrangements accepted by accountable care organizations, putting pressure on clinical-care teams and their organizations to justify that what they do is the most cost-effective option [9]. Altering care delivery patterns can reduce costs [3], but not invariably [10].

\section{Characteristics of the New System}

\subsection{Self-Management}

Self-management has been defined as "an individual's ability to detect and manage symptoms, treatment, physical and psychosocial consequences, and lifestyle changes inherent in living with a chronic condition" [11]. Others suggest that self-management of medical conditions involves three tasks-medical management, role management, and emotional management [12].

Also defined as an integrated coordination of healthcare interventions and actions for populations with chronic conditions, self-management "supports the physician or practitioner/patient relationship and plan of care; emphasizes prevention of exacerbations and complications through the use of evidence-based practice guidelines and patient empowerment strategies; and evaluates outcomes on an ongoing basis with the goal of improving overall health" [13]. We parse this sentence beginning with "integrated coordination supports the physician or practitioner/patient relation and plan of care.".

The Federal Health IT Strategic Plan: 2015-2020 has as its first goal, "Advance Person-Centered and Self-Managed Health" [14]. This is to be achieved by empowering the individual, the family, and the caregiver health management and engagement.

The coordination of care among multiple clinicians, results in what has come to be called "family-centered care" [15-17]. Emphasizing "patient empowerment strategies," this approach encourages patients and caregivers to participate in the care [18-20], fosters medication adherence [21], helps family members cope [22], and increases self-esteem, and quality of life [23].

Engaging the patient and her family can also be enhanced with assistance navigating service systems [24]. Programs that do this, appear to improve coping and increase the use of community-based services and resources. Parent education programs also improve parents' mental health, as well as communication and problem-solving skills [25].

We continue parsing the introductory sentence and focus now on "evaluates outcomes on an ongoing basis." Although repeatedly completing forms that require patients or care-givers to identify problems, rate their magnitude, and identify their priority might seem like a burden, some families have felt that using the ePROs had several potential benefits, including an aid to remember something they wanted to discuss with the clinical-care team, and making the next consultation more efficient and patient-centered [26]. (Please see the next section on remote surveillance for more on this topic.)

Self-management includes all the activities that patients and their families do, to increase health-related quality of life, such as identifying and avoiding triggers that exacerbate symptoms, and adherence to prescribed medications and other therapies [27]. Questionnaires not only assess, but can also expand the self-management knowledge [28-32]. 
Often patients and their families need help with self-management [11,33]. "Supporting self-management is about helping patients to develop skills such as problem solving, setting goals, accepting change, finding coping strategies, managing relationships through communication, and finding quality of life in difficult circumstances" [34]. By providing support, physician and nurse clinicians [35,36], and pharmacists [37] can help people acquire each of these skill sets, as well as facilitate self-management in other ways [38]. Unfortunately, clinicians do not always have sufficient training, time, resources, or appropriate skills or confidence to provide effective self-management support $[39,40]$.

Multiple techniques are used to maximize patient/family engagement in self-management, including increased support from clinicians [35], education about the person's disease and available self-management resources [28-32,39], prompts to increase shared decision-making with the clinicians [41], and customizing the available options [42,43].

What is needed to engage patients and their families appears to be influenced, in part, by the needs posed by the medical condition. For example, the difficulties some parents experience in "navigating service systems, finding information about their child's condition, and accessing health care and community resources" can be minimized by having "interventions that "activate" parents of children with special health care needs to increase their knowledge, skills, and confidence in managing, coordinating, and advocating for their child's needs" [24].

While most measurements of the success of self-management focus on medication adherence, the need exists for improved assessments of symptom reduction capabilities [44]. Self-management programs have proven successful in improving the attainment of goals for the care of diabetes and hypertension [45]. They also hold promise for the self-management of asthma [46]. Visualization of symptom reduction by the patients and their families could further reinforce self-management by providing feedback and a greater sense of control.

\subsection{Electronic Capabilities}

One of the early clearer definitions of e-health is "the combined use of electronic communication and information technology in the health sector" [47]. Nevertheless, a decade later, one author claimed that no definition is yet well-accepted [48]. At about that time, The World Health Organization (WHO) defined e-Health as 'the transfer of health resources and healthcare by electronic means' [49].

In another report, the World Health Organization defined mHealth as "the use of mobile and wireless technologies to support the achievement of health objectives" [50]. Sensors (both wearable, and in place) hold the promise of providing clinicians with previously-unavailable information that might even be lifesaving [51]. A total of $80 \%$ of adults with an implanted cardioverter defibrillator or cardiac resynchronization device accept remote monitoring [52], which appears to reduce in-hospital visit numbers, time required for patient follow-up, physician and nurse time, and hospital and social costs [53].

"To deliver better health care at a lower cost, health information technology (IT) should be redesigned to support improved, patient-centered care, and not the isolated tasks of physicians and clinicians" [54]. Smart phone apps have the potential to improve self-management interventions [55,56]. The most common features of these apps are "real-time or frequent periodic symptom assessments, pre-programed reminders, and feedbacks tailored specifically to the data provided by participants" [57].

Some systems now collect physiological data remotely, using "off-the-shelf" easy-to-use components geared towards the sports or entertainment market [58]. Although some of the commercially available apps appear to have the potential to promote self-management $[59,60]$, very few studies have integrated physiological data with health care personnel communication [61].

Mobile phone messaging applications, such as Short Message Service (SMS) and Multimedia Message Service (MMS), can provide medication reminders, therapy adjustments, and supportive messages. Although they, thus, offer the promise of supporting self-management, the evidence that they help achieve these goals remains limited [62,63]. The evidence is accruing, however, that mobile 
technologies can help treat heart failure [64-66], hypertension [66,67], asthma [68-70], depression [71], diabetes [72-76], overweight, and obesity [77], and also enhance medication adherence [78,79].

Both data encryption and data quality requirements differ for medical care and recreational device use [80]. In addition, barriers to the acceptance and spread of mHealth are abundant [81]. Nevertheless, mHealth and related technologies appear to be increasingly accepted [82-84].

The effectiveness of mHealth technologies to relay critical information in real-time, apparently depends on the strength of the communication loop between patients and health care professionals [85]. Patient (or caregiver)-provided or sensor-provided data can be sorted by level of urgency defined by customized algorithms and be distributed to the most appropriate recipient. Only non-physician members of the health team screen communications about changes from the status quo that are deemed modest and non-critical. Values beyond the critical thresholds defined for each patient, according to the physicians' preference, trigger alerts that are sent both to the patient's non-physician clinical team and her/his physician. Messages labeled as urgent or high priority by the patient or caregiver can also be disseminated among the non-physician clinical care team members and physicians.

The use of information and communication technologies to deliver healthcare at a distance, also supports "patient self-management through remote monitoring and personalised feedback" [86]. These appear to be especially effective for adults with severe chronic diseases, who are at a high-risk of hospitalization and death [86].

The term "patient portal" also has had multiple definitions $[87,88]$. The federal government uses the term "patient portal" for a secure web site, integrated with the electronic health record (EHR), that allows the patient to complete forms, access personal health information such as problem lists, current medications, immunization history, laboratory data, and radiology reports, schedule appointments, and request prescription refills [89]. These portals, which allow patients electronic access to appointment scheduling, medication refills, and secure communication with their provider or care team, seem to improve "medication adherence, disease awareness, self-management of disease, a decrease of office visits, and an increase in disease-prevention behaviors" [90].

Although initially slow, acceptance of patient portals is now increasing [91]. Teaching patients how to access the portal appears to increase the portal use, as does providing answers to questions about information obtained via the portal [91].

Some patient portals also allow electronic communication with healthcare providers, although this feature is often described as secure messaging, which the Centers for Medicare and Medicaid Services (CMS) define as "any electronic communication between a provider and patient that ensures only those parties can access the communication. This electronic message could be email or the electronic messaging function of $\ldots$ an online patient portal, or any other electronic means" [92]. The name "eVisits" has been applied to structured communications about symptoms [93].

The messages are encrypted and integrity-protected, in accordance with the standards for encryption and hashing algorithms. In the United States, any electronic communication between patient and provider needs to conform to the regulations in the Health Insurance Portability and Accountability Act (HIPAA) [94].

Acceptance of secure messaging by patients was initially slow, but has since accelerated [95]. Secure messaging has the potential to improve medication adherence and clinic attendance [96], increase patient satisfaction, be accepted as convenient, time-saving, and useful, as well as reduce the costs for the patient [97]. On the other hand, these benefits have come with increased burdens on healthcare providers and staff [98], and by extension—at least initially-apparently increased costs for the institution providing the medical care.

A patient-reported outcome (PRO) is the information provided by a patient or caregiver about what the person is able to do and how that person feels $[99,100]$. PROs provide what cannot be measured in any way other than from the patient, the family, or the caregiver [101].

Patient-reported information about fatigue, anxiety, depression, and sleep disturbance, not only helps the clinician identify side effects of medications [102], but can also help the clinician 
understand why an increase in chronic recurrent symptoms or disease exacerbation had occurred recently [103]. PROs have the potential "to improve quality of care and disease outcomes, provide patient-centered assessment for comparative effectiveness research, and enable a common metric for tracking outcomes across providers and medical systems" [104]. This will be possible when PROs are standardized $[105,106]$. Unfortunately, we are not there yet. The implementation of PROs into clinical care has been facilitated by their documented validity, the rapid progression of technology, and greater demand for measurement and monitoring of PROs by regulators (especially the FDA), payers, accreditors, and professional organizations [107].

e-PRO is a term used by some to indicate electronic-entered PROs, which provide information comparable to that provided by questionnaires completed on paper [108-110], and have the added benefit of not requiring separate data entry. Sometimes the entry is at the time of the visit with the clinician, either via a kiosk [111] or a tablet [112]. When this is completed before seeing the clinician, the information can be available just before or during the visit.

We recommend entry of e-PROs in real-time and remotely. These e-PROs can then be used to screen for deterioration of adverse events $[105,113]$, and can identify clinically-significant events or changes [114]. For example, patients or their caregivers can provide asthmatic attack information in real-time that can readily be entered into the EHR [115]. This information can prompt intervention when indicated (v.i., alerts) [116]. Conversely, when all is well, information about the absence of changes and deterioration can justify delaying the next visit, thereby helping to reduce the frequency of (unnecessary) outpatient visits [64,117].

With physicians increasingly accepting the value of ePROs [118-121], the data collected routinely can include measures of satisfaction with care, and drug adherence [122]. PROs also appear to contribute to improved communication and diagnosis/treatment, and to a lesser extent, more favorable outcomes $[19,105,123]$. Some PROs are particularly effective at identifying mental health conditions $[124,125]$.

The systematic monitoring of the health-related quality of life (HRQoL) is being increasingly encouraged [117,126-130]. HRQoL tools have the potential to improve patient-physician communication, "strengthen information exchange" and improve care [131]. In one study of routine cancer care, patients randomized to provide ePROs had a higher HRQoL than the comparison group, and also had a modestly (6\%) higher 12-month overall survival, and a modestly lower $(7 \%)$ rate of admission to the emergency room [132]. In another study of adult cancer patients who completed PROs, those who had the opportunity to discuss the PRO contents with the clinician, subsequently had higher HRQoLs than those deprived of this opportunity [133]. However, not all HRQoL instruments are equivalent, prompting a call for "greater consensus of content across different HRQoL instruments" [134]. This is not easily achieved in light of the propensity to use "disease-specific" quality of life measures [135]. Diaries tracking the occurrence of medical events and treatments are also a form of patient-reported outcome [136].

The National Heart, Lung, and Blood Institute's Expert Panel Guidelines for the Diagnosis and Management of Asthma recommends that clinicians should encourage patients who have asthma (and their families) to use self-assessment tools of asthma control, such as a daily diary [137]. Electronic diaries for entry of symptoms and pulmonary functions, are not only acceptable, but are also helpful in improving control [138-142].

Diaries, especially electronic diaries, can be added to the her or even entered directly. They exemplify our goal of having the patient (or caregiver) enrich the EMR, without an intermediary filtering out and perhaps inappropriately changing what was provided as truth.

Patient-generated health data (PGHD) are defined as "health-related data including health history, symptoms, biometric data, treatment history, lifestyle choices, and other information-created, recorded, gathered, or inferred by or from patients or their designees (i.e., care partners or those who assist them) to help address a health concern" [143]. PGHD differ from e-PROs, in including sensor- or device-generated data $[144,145]$, and not requiring that the data be entered directly into the EMR. 
On the other hand, having the patient enter his/her own data into the EMR, offers the promise of improved collaboration between the patient and the provider [146], and improved identification of adverse drug reactions [147].

\subsection{Borrowing from a Slightly Older Model: The Medical Home}

The term "medical home" was first used to describe the coordination of, and communication among, multiple sources of medical care for children with complex medical needs [148,149]. Although the terms "medical home" and "patient-centered medical home" (PCMH) continue to be used, "care coordination" [15,150-153], "integrated care" [154-157], and "medical neighborhood" [158-161] also appear to be used frequently. Both pediatricians [150,162] and internists [163] embrace the patient-centered medical home for patients with complex needs. Nevertheless, adoption rates are less than desired [154,157,164,165].

The shared characteristics of these concepts include coordination of care among professionals, facilities, and support systems; continuity of care (i.e., between office/clinic visits); modification of care to meet each patient's (and family's) needs and preferences; and sharing of responsibility between patient and caregivers to achieve the common goals of coordinated care [166]. Each of these components is a part of the system of medical care we expect will apply to the delivery of care in accountable care organizations.

Low provider reimbursement has been offered as one reason for the low adoption of coordinated care management practices $[153,159,167]$. Provider reimbursement is also likely to influence how well the "new patient care model" is adopted and implemented. Also likely to influence the "new patient care model", is the evidence that information technologies might be able to enhance efforts to achieve care coordination [151,152].

\subsection{Acceptance of New Technologies}

The acceptance of information technology can be viewed in light of four constructs, performance expectancy, effort expectancy, facilitating conditions, and social influences [168]. Among the facilitating conditions are, improved electronic systems, flexibility of collection location, and integration with patient health care data elements $[107,169]$. Older children, adolescents, caregivers, and clinicians all viewed PROs as having the potential to alter the scope of clinical discussions favorably, although not always for the same reasons [170-172].

Physicians have shown some hesitance about implementing e-health, because of potential overload due to the additional work of reading emails and reviewing other electronic data, and the need to detail the EMR during the patient's visit might degrade the patient-physician relationship [173]. Then again, how will reimbursement deal with the increased workload? How will data safety and patient privacy be preserved?

\subsection{Remote Surveillance}

We use the terms 'remote surveillance' and 'remote monitoring' for the collection of information from the patient when she/he is not in the office/clinic or in the hospital. Others use such terms as 'remote patient monitoring' [174], 'remote monitoring of patient self-care' [175], and 'lifestyle monitoring' [176].

Monitoring can be continuous and non-obtrusive, as exemplified by the monitoring of patients who have an implanted ventricular pacemaker. Monitoring can also be intermittent and very intense (daily telephone report of weight and symptoms, supplemented by reports from home-care services and individualized home visits by a clinician) [177], or it can be intermittent and less intense when the patient's complete their own diaries and other ePROs. Remote surveillance has helped reduce mortality, visits to the emergency department, and hospital admissions [65,177-182].

The new goal is reducing the need for visits to the office/clinic [183]. With sufficiently-frequent patient- or caregiver-provided reports, the clinician can decide whether a patient needs an outpatient 
visit, medication adjustment, or watchful waiting, thereby, allowing more flexible, targeted, and cost-saving chronic-disease care $[7,184-186]$. Indeed, clinicians seem to value timely electronic patient-reports of symptoms and other characteristics/events [187-190]. Patients also appreciate the telemonitoring because it provides reassurance of continuous practitioner surveillance [191].

\subsection{Alerts}

The natural history of every disease can be viewed as comprised of a continuum of multiple steps, along a trajectory of progression. At each stage, the probability of moving to the next stage can vary at any time [192]. Machine-learning architecture can systematize the procedures needed to assign patients to the most appropriate level of surveillance [58,193].

Electronic alerts are intended to call attention to the patient's increasing probability of moving to the next step along the path, to more severe symptoms. The presumed value of such alerts is that if the clinician intervenes, she/he might be able to limit progression to the next stage. This might hold for episodic disorders, such as asthma, diabetes, and epilepsy [194], just as it might hold for acute kidney dysfunction [195-197], and cancer [8,198-201].

\section{The Future}

We suggest that the four-components of the new health-care systems we envisioned, (i.e., increased self-management, reliance on electronic patient-reported outcomes, remote surveillance of patient-provided communications, and systems that alert medical care providers when intervention might be appropriate) have a bright future. Yes, obstacles will occur along the way, with more road-blocks than simple bumps. On the other hand, the economic $[202,203]$ and social pressures (e.g., increasing use of electronic technology) [204,205], to increase patient empowerment [206-208]) are likely to be insurmountable.

We also envision the sharing of ePROs (and other relevant data contained within a medical-care organization) with an "information commons" consisting of networks that are prepared to share such information [209-212]. This will allow the clinician to query if patients similar to theirs also have insomnia since they have started a new medication.

Author Contributions: All authors contributed to writing and revising this manuscript.

Funding: This report was supported by an Epilepsy Research Fund (EpiViz).

Conflicts of Interest: The authors declare no conflict of interest.

\section{References}

1. Perla, R.J.; Pham, H.; Gilfillan, R.; Berwick, D.M.; Baron, R.J.; Lee, P.; McCannon, C.J.; Progar, K.; Shrank, W.H. Government As Innovation Catalyst: Lessons From The Early Center For Medicare And Medicaid Innovation Models. Health Aff. 2018, 37, 213-221. [CrossRef] [PubMed]

2. McClellan, M.; Udayakumar, K.; Thoumi, A.; Gonzalez-Smith, J.; Kadakia, K.; Kurek, N.; Abdulmalik, M.; Darzi, A.W. Improving Care And Lowering Costs: Evidence And Lessons From A Global Analysis Of Accountable Care Reforms. Health Aff. 2017, 36, 1920-1927. [CrossRef]

3. Hsu, J.; Price, M.; Vogeli, C.; Brand, R.; Chernew, M.E.; Chaguturu, S.K.; Weil, E.; Ferris, T.G. Bending The Spending Curve By Altering Care Delivery Patterns: The Role Of Care Management Within A Pioneer ACO. Health Aff. 2017, 36, 876-884. [CrossRef] [PubMed]

4. Bates, D.W.; Sheikh, A.; Asch, D.A. Innovative Environments In Health Care: Where And How New Approaches To Care Are Succeeding. Health Aff. 2017, 36, 400-407. [CrossRef] [PubMed]

5. Miller, P. The Medical Profession's Future: A Struggle Between Caring For Patients And Bottom-Line Pressures. Health Aff. 2016, 35, 407-410. [CrossRef] [PubMed]

6. Wicks, P.; Hotopf, M.; Narayan, V.A.; Basch, E.; Weatherall, J.; Gray, M. It's a long shot, but it just might work! Perspectives on the future of medicine. BMC Med. 2016, 14, 176. [CrossRef] 
7. Schougaard, L.M.; Mejdahl, C.T.; Petersen, K.H.; Jessen, A.; de Thurah, A.; Sidenius, P.; Lomborg, K.; Hjollund, N.H. Effect of patient-initiated versus fixed-interval telePRO-based outpatient follow-up: Study protocol for a pragmatic randomised controlled study. BMC Health Serv. Res. 2017, 17, 83. [CrossRef]

8. Absolom, K.; Holch, P.; Warrington, L.; Samy, F.; Hulme, C.; Hewison, J.; Morris, C.; Bamforth, L.; Conner, M.; Brown, J.; et al. Electronic patient self-Reporting of Adverse-events: Patient Information and aDvice (eRAPID): A randomised controlled trial in systemic cancer treatment. BMC Cancer 2017, 17, 318. [CrossRef]

9. Lewis, V.A.; Tierney, K.I.; Fraze, T.; Murray, G.F. Care Transformation Strategies and Approaches of Accountable Care Organizations. Med. Care Res. Rev. MCRR 2017. [CrossRef] [PubMed]

10. McWilliams, J.M.; Chernew, M.E.; Landon, B.E. Medicare ACO Program Savings Not Tied To Preventable Hospitalizations Or Concentrated Among High-Risk Patients. Health Aff. 2017, 36, 2085-2093. [CrossRef]

11. Barlow, J.; Wright, C.; Sheasby, J.; Turner, A.; Hainsworth, J. Self-management approaches for people with chronic conditions: A review. Patient Educ. Couns. 2002, 48, 177-187. [CrossRef]

12. Corbin, J.; Strauss, A. Unending Work and Care: Managing Chronic Illness at Home; Jossey-Bass: San Francisco, CA, USA, 1988.

13. Mercer, V. Chronic disease management. In Stepped Care and e-Health: Practical Applications to Behavioral Disorders; O'donohue, W.T., Draper, C., Eds.; Springer: New York, NY, USA, 2011; pp. 151-179.

14. Federal Health IT Strategic Plan: 2015-2020. Available online: https:/dashboard.healthit.gov/strategic-plan/ federal-health-it-strategic-plan-vision-mission-principles.php (accessed on 5 November 2018).

15. Antonelli, R.C.; Stille, C.J.; Antonelli, D.M. Care coordination for children and youth with special health care needs: A descriptive, multisite study of activities, personnel costs, and outcomes. Pediatrics 2008, 122, e209-e216. [CrossRef] [PubMed]

16. Turchi, R.M.; Gatto, M.; Antonelli, R. Children and youth with special healthcare needs: There is no place like (a medical) home. Curr. Opin. Pediatr. 2007, 19, 503-508. [CrossRef]

17. Turchi, R.M.; Antonelli, R.C.; Norwood, K.W.; Adams, R.C.; Brei, T.J.; Burke, R.T.; Davis, B.E.; Friedman, S.L.; Houtrow, A.J.; Kuo, D.Z.; et al. Patient- and family-centered care coordination: A framework for integrating care for children and youth across multiple systems. Pediatrics 2014, 133, e1451-e1460. [CrossRef]

18. Hibbard, J.H. Engaging health care consumers to improve the quality of care. Med. Care 2003, 41, I61-I70. [CrossRef]

19. Haywood, K.; Marshall, S.; Fitzpatrick, R. Patient participation in the consultation process: A structured review of intervention strategies. Patient Educ. Couns. 2006, 63, 12-23. [CrossRef]

20. Fiks, A.G.; Mayne, S.; Karavite, D.J.; DeBartolo, E.; Grundmeier, R.W. A shared e-decision support portal for pediatric asthma. J. Ambul. Care Manag. 2014, 37, 120-126. [CrossRef]

21. Nafradi, L.; Nakamoto, K.; Schulz, P.J. Is patient empowerment the key to promote adherence? A systematic review of the relationship between self-efficacy, health locus of control and medication adherence. PLoS ONE 2017, 12, e0186458. [CrossRef] [PubMed]

22. Duffy, L.V.; Vessey, J.A. A Randomized Controlled Trial Testing the Efficacy of the Creating Opportunities for Parent Empowerment Program for Parents of Children With Epilepsy and Other Chronic Neurological Conditions. J. Neurosci. Nurs. J. Am. Assoc. Neurosci. Nurses 2016, 48, 166-174. [CrossRef] [PubMed]

23. Buttitta, M.; Rousseau, A.; Guerrien, A. A New Understanding of Quality of Life in Children and Adolescents with Obesity: Contribution of the Self-determination Theory. Curr. Obes. Rep. 2017, 6, 432-437. [CrossRef]

24. Mirza, M.; Krischer, A.; Stolley, M.; Magana, S.; Martin, M. Review of parental activation interventions for parents of children with special health care needs. Child Care Health Dev. 2018, 44, 401-426. [CrossRef]

25. Jackson, A.C.; Liang, R.P.; Frydenberg, E.; Higgins, R.O.; Murphy, B.M. Parent education programmes for special health care needs children: A systematic review. J. Clin. Nurs. 2016, 25, 1528-1547. [CrossRef] [PubMed]

26. Protheroe, J.; Blakeman, T.; Bower, P.; Chew-Graham, C.; Kennedy, A. An intervention to promote patient participation and self-management in long term conditions: Development and feasibility testing. BMC Health Serv. Res. 2010, 10, 206. [CrossRef]

27. Schulman-Green, D.; Jaser, S.; Martin, F.; Alonzo, A.; Grey, M.; McCorkle, R.; Redeker, N.S.; Reynolds, N.; Whittemore, R. Processes of self-management in chronic illness. J. Nurs. Scholarsh. 2012, 44, 136-144. [CrossRef] [PubMed] 
28. Baygul, A.; Ozturk, A.B.; Ozyigit, L.P.; Keskin, H.; Karakaya, G.; Kalyoncu, F.; Senocak, M.S. The Reliability and Validation of the Turkish Version of the Asthma Self-Management Knowledge Questionnaire. Turk. Thorac. J. 2017, 18, 125-130. [CrossRef]

29. Beck, J.; Greenwood, D.A.; Blanton, L.; Bollinger, S.T.; Butcher, M.K.; Condon, J.E.; Cypress, M.; Faulkner, P.; Fischl, A.H.; Francis, T.; et al. 2017 National Standards for Diabetes Self-Management Education and Support. Diabetes Educ. 2018, 44, 35-50. [CrossRef]

30. Modi, A.C.; Monahan, S.; Daniels, D.; Glauser, T.A. Development and validation of the Pediatric Epilepsy Medication Self-Management Questionnaire. Epilepsy Behav. 2010, 18, 94-99. [CrossRef] [PubMed]

31. Loiselle, K.A.; Ramsey, R.R.; Rausch, J.R.; Modi, A.C. Trajectories of Health-Related Quality of Life Among Children With Newly Diagnosed Epilepsy. J. Pediatr. Psychol. 2016, 41, 1011-1021. [CrossRef] [PubMed]

32. Morita, D.A.; Glauser, T.A.; Modi, A.C. Development and validation of the Pediatric Epilepsy Side Effects Questionnaire. Neurology 2012, 79, 1252-1258. [CrossRef] [PubMed]

33. Van der Molen, T.; Fletcher, M.; Price, D. Identifying Patient Attitudinal Clusters Associated with Asthma Control: The European REALISE Survey. J. Allergy Clin. Immunol. Pract. 2018, 6, 962-971. [CrossRef] [PubMed]

34. De Iongh, A. Patients need support to self manage their long term conditions. BMJ 2014, 348 , g2973. [CrossRef] [PubMed]

35. Adams, K.; Greiner, A.C.; Corrigan, J.M. Crossing the Quality Chasm: Next Steps Toward a New Health Care System; National Academy Press: Washington, DC, USA, 2004.

36. Gray, W.N.; Netz, M.; McConville, A.; Fedele, D.; Wagoner, S.T.; Schaefer, M.R. Medication adherence in pediatric asthma: A systematic review of the literature. Pediatr. Pulmonol. 2018. [CrossRef] [PubMed]

37. Van Eikenhorst, L.; Taxis, K.; van Dijk, L.; de Gier, H. Pharmacist-Led Self-management Interventions to Improve Diabetes Outcomes. A Systematic Literature Review and Meta-Analysis. Front. Pharmacol. 2017, 8, 891. [CrossRef]

38. De Iongh, A.; Fagan, P.; Fenner, J.; Kidd, L. A practical guide to self-management support. Available online: http://www.health.org.uk/sites/health/files/APracticalGuideToSelfManagementSupport.pdf (accessed on 26 March 2018).

39. Russell, S.; Ogunbayo, O.J.; Newham, J.J.; Heslop-Marshall, K.; Netts, P.; Hanratty, B.; Beyer, F.; Kaner, E. Qualitative systematic review of barriers and facilitators to self-management of chronic obstructive pulmonary disease: Views of patients and healthcare professionals. NPJ Prim. Care Respir. Med. 2018, 28, 2. [CrossRef]

40. Davies, F.; Wood, F.; Bullock, A.; Wallace, C.; Edwards, A. Shifting mindsets: A realist synthesis of evidence from self-management support training. Med. Educ. 2018, 52, 274-287. [CrossRef] [PubMed]

41. Hubner, L.M.; Feldman, H.M.; Huffman, L.C. Parent Communication Prompt to Increase Shared Decision-Making: A New Intervention Approach. Front. Pediatr. 2018, 6, 60. [CrossRef] [PubMed]

42. Atkinson-Clark, E.; Charokopou, M.; Van Osselaer, N.; Hiligsmann, M. A discrete-choice experiment to elicit preferences of patients with epilepsy for self-management programs. Epilepsy Behav. 2018, 79, 58-67. [CrossRef]

43. Kulnik, S.T.; Hollinshead, L.; Jones, F. "I'm still me-I'm still here!” Understanding the person's sense of self in the provision of self-management support for people with progressive neurological long-term conditions. Disabil. Rehabil. 2018, 1-11. [CrossRef]

44. Smith, G.; Modi, A.C.; Johnson, E.K.; Shegog, R.; Austin, J.K.; Wagner, J.L. Measurement in pediatric epilepsy self-management: A critical review. Epilepsia 2018, 59, 509-522. [CrossRef]

45. Reynolds, R.; Dennis, S.; Hasan, I.; Slewa, J.; Chen, W.; Tian, D.; Bobba, S.; Zwar, N. A systematic review of chronic disease management interventions in primary care. BMC Fam. Pract. 2018, 19, 11. [CrossRef]

46. Costello, R.W.; Dima, A.L.; Ryan, D.; McIvor, R.A.; Boycott, K.; Chisholm, A.; Price, D.; Blakey, J.D. Effective deployment of technology-supported management of chronic respiratory conditions: A call for stakeholder engagement. Pragmat. Obs. Res. 2017, 8, 119-128. [CrossRef]

47. Della Mea, V. What is e-health (2): The death of telemedicine? J. Med. Internet Res. 2001, 3, e22. [CrossRef] [PubMed]

48. Showell, C.; Nohr, C. How should we define eHealth, and does the definition matter? Stud. Health Technol. Inform. 2012, 180, 881-884.

49. World Health Organization. mHealth: New Horizons for Health through Mobile Technologies. Based on the Findings of the Second Global Survey on eHealth; World Health Organization: Geneva, Switzerland, 2011. 
50. Kay, M.; Santos, J.; Takane, M. mHealth. New Horizons for Health through Mobile Technologies. Available online: http://www.who.int/goe/publications/goe_mhealth_web.pdf (accessed on 11 October 2017).

51. Hindricks, G.; Taborsky, M.; Glikson, M.; Heinrich, U.; Schumacher, B.; Katz, A.; Brachmann, J.; Lewalter, T.; Goette, A.; Block, M.; et al. Implant-based multiparameter telemonitoring of patients with heart failure (IN-TIME): A randomised controlled trial. Lancet 2014, 384, 583-590. [CrossRef]

52. Rosenfeld, L.E.; Patel, A.S.; Ajmani, V.B.; Holbrook, R.W.; Brand, T.A. Compliance with remote monitoring of ICDS/CRTDS in a real-world population. Pacing Clin. Electrophysiol. 2014, 37, 820-827. [CrossRef] [PubMed]

53. Varma, N.; Ricci, R.P. Impact of Remote Monitoring on Clinical Outcomes. J. Cardiovasc. Electrophysiol. 2015, 26, 1388-1395. [CrossRef] [PubMed]

54. Walker, J.M.; Carayon, P. From tasks to processes: The case for changing health information technology to improve health care. Health Aff. 2009, 28, 467-477. [CrossRef]

55. Whitehead, L.; Seaton, P. The Effectiveness of Self-Management Mobile Phone and Tablet Apps in Long-term Condition Management: A Systematic Review. J. Med. Internet Res. 2016, 18, e97. [CrossRef] [PubMed]

56. Changizi, M.; Kaveh, M.H. Effectiveness of the mHealth technology in improvement of healthy behaviors in an elderly population-a systematic review. mHealth 2017, 3, 51. [CrossRef]

57. Lee, J.A.; Choi, M.; Lee, S.A.; Jiang, N. Effective behavioral intervention strategies using mobile health applications for chronic disease management: A systematic review. BMC Med. Inform. Decis. Mak. 2018, 18, 12. [CrossRef]

58. Holthe, H.; Serrano, J.A. ePoint.telemed-An Open Web-based Platform for Home Monitoring of Patients with Chronic Heart Failure. Stud. Health Technol. Inform. 2015, 216, 74-78.

59. Froisland, D.H.; Arsand, E.; Skarderud, F. Improving diabetes care for young people with type 1 diabetes through visual learning on mobile phones: Mixed-methods study. J. Med. Internet Res. 2012, 14 , e111. [CrossRef] [PubMed]

60. Chomutare, T.; Fernandez-Luque, L.; Arsand, E.; Hartvigsen, G. Features of mobile diabetes applications: Review of the literature and analysis of current applications compared against evidence-based guidelines. J. Med. Internet Res. 2011, 13, e65. [CrossRef]

61. Holmen, H.; Wahl, A.K.; Cvancarova Smastuen, M.; Ribu, L. Tailored Communication Within Mobile Apps for Diabetes Self-Management: A Systematic Review. J. Med. Internet Res. 2017, 19, e227. [CrossRef]

62. de Jongh, T.; Gurol-Urganci, I.; Vodopivec-Jamsek, V.; Car, J.; Atun, R. Mobile phone messaging for facilitating self-management of long-term illnesses. Cochrane Database Syst. Rev. 2012, 12, CD007459. [CrossRef] [PubMed]

63. Marcolino, M.S.; Oliveira, J.A.Q.; D’Agostino, M.; Ribeiro, A.L.; Alkmim, M.B.M.; Novillo-Ortiz, D. The Impact of mHealth Interventions: Systematic Review of Systematic Reviews. JMIR mHealth uHealth 2018, 6, e23. [CrossRef] [PubMed]

64. Kraai, I.; de Vries, A.; Vermeulen, K.; van Deursen, V.; van der Wal, M.; de Jong, R.; van Dijk, R.; Jaarsma, T.; Hillege, H.; Lesman, I. The value of telemonitoring and ICT-guided disease management in heart failure: Results from the IN TOUCH study. Int. J. Med. Inform. 2016, 85, 53-60. [CrossRef]

65. Bashi, N.; Karunanithi, M.; Fatehi, F.; Ding, H.; Walters, D. Remote Monitoring of Patients with Heart Failure: An Overview of Systematic Reviews. J. Med. Internet Res. 2017, 19, e18. [CrossRef]

66. Coorey, G.M.; Neubeck, L.; Mulley, J.; Redfern, J. Effectiveness, acceptability and usefulness of mobile applications for cardiovascular disease self-management: Systematic review with meta-synthesis of quantitative and qualitative data. Eur. J. Prev. Cardiol. 2018, 25, 505-521. [CrossRef]

67. Kaplan, A.L.; Cohen, E.R.; Zimlichman, E. Improving patient engagement in self-measured blood pressure monitoring using a mobile health technology. Health Inf. Sci. Syst. 2017, 5, 4. [CrossRef] [PubMed]

68. Farzandipour, M.; Nabovati, E.; Sharif, R.; Arani, M.H.; Anvari, S. Patient Self-Management of Asthma Using Mobile Health Applications: A Systematic Review of the Functionalities and Effects. Appl. Clin. Inform. 2017, 8, 1068-1081. [CrossRef]

69. Pinnock, H.; Parke, H.L.; Panagioti, M.; Daines, L.; Pearce, G.; Epiphaniou, E.; Bower, P.; Sheikh, A.; Griffiths, C.J.; Taylor, S.J. Systematic meta-review of supported self-management for asthma: A healthcare perspective. BMC Med. 2017, 15, 64. [CrossRef]

70. Halterman, J.S.; Fagnano, M.; Tajon, R.S.; Tremblay, P.; Wang, H.; Butz, A.; Perry, T.T.; McConnochie, K.M. Effect of the School-Based Telemedicine Enhanced Asthma Management (SB-TEAM) Program on Asthma Morbidity: A Randomized Clinical Trial. JAMA Pediatr. 2018, 172, e174938. [CrossRef] 
71. Hantsoo, L.; Criniti, S.; Khan, A.; Moseley, M.; Kincler, N.; Faherty, L.J.; Epperson, C.N.; Bennett, I.M. A Mobile Application for Monitoring and Management of Depressed Mood in a Vulnerable Pregnant Population. Psychiatr. Serv. 2018, 69, 104-107. [CrossRef] [PubMed]

72. Fortmann, A.L.; Gallo, L.C.; Garcia, M.I.; Taleb, M.; Euyoque, J.A.; Clark, T.; Skidmore, J.; Ruiz, M.; Dharkar-Surber, S.; Schultz, J.; et al. Dulce Digital: An mHealth SMS-Based Intervention Improves Glycemic Control in Hispanics With Type 2 Diabetes. Diabetes Care 2017, 40, 1349-1355. [CrossRef]

73. Kitsiou, S.; Pare, G.; Jaana, M.; Gerber, B. Effectiveness of mHealth interventions for patients with diabetes: An overview of systematic reviews. PLoS ONE 2017, 12, e0173160. [CrossRef] [PubMed]

74. Xu, T.; Pujara, S.; Sutton, S.; Rhee, M. Telemedicine in the Management of Type 1 Diabetes. Prev. Chronic Dis. 2018, 15, e13. [CrossRef] [PubMed]

75. Zhai, Y.K.; Zhu, W.J.; Cai, Y.L.; Sun, D.X.; Zhao, J. Clinical- and cost-effectiveness of telemedicine in type 2 diabetes mellitus: A systematic review and meta-analysis. Medicine 2014, 93, e312. [CrossRef]

76. Ryan, E.A.; Holland, J.; Stroulia, E.; Bazelli, B.; Babwik, S.A.; Li, H.; Senior, P.; Greiner, R. Improved A1C Levels in Type 1 Diabetes with Smartphone App Use. Can. J. Diabetes 2017, 41, 33-40. [CrossRef]

77. Chin, S.O.; Keum, C.; Woo, J.; Park, J.; Choi, H.J.; Woo, J.T.; Rhee, S.Y. Successful weight reduction and maintenance by using a smartphone application in those with overweight and obesity. Sci. Rep. 2016, 6, 34563. [CrossRef] [PubMed]

78. Rootes-Murdy, K.; Glazer, K.L.; Van Wert, M.J.; Mondimore, F.M.; Zandi, P.P. Mobile technology for medication adherence in people with mood disorders: A systematic review. J. Affect. Disord. 2017, 227, 613-617. [CrossRef]

79. Badawy, S.M.; Thompson, A.A.; Kuhns, L.M. Medication Adherence and Technology-Based Interventions for Adolescents with Chronic Health Conditions: A Few Key Considerations. JMIR mHealth uHealth 2017, 5, e202. [CrossRef] [PubMed]

80. Filkins, B.L.; Kim, J.Y.; Roberts, B.; Armstrong, W.; Miller, M.A.; Hultner, M.L.; Castillo, A.P.; Ducom, J.C.; Topol, E.J.; Steinhubl, S.R. Privacy and security in the era of digital health: What should translational researchers know and do about it? Am. J. Transl. Res. 2016, 8, 1560-1580.

81. Mohammadzadeh, N.; Safdari, R. Patient monitoring in mobile health: Opportunities and challenges. Med. Arch. 2014, 68, 57-60. [CrossRef] [PubMed]

82. Baig, M.M.; GholamHosseini, H.; Moqeem, A.A.; Mirza, F.; Linden, M. A Systematic Review of Wearable Patient Monitoring Systems-Current Challenges and Opportunities for Clinical Adoption. J. Med. Syst. 2017, 41, 115. [CrossRef] [PubMed]

83. Handayani, P.W.; Hidayanto, A.N.; Budi, I. User acceptance factors of hospital information systems and related technologies: Systematic review. Inform. Health Soc. Care 2017, 43, 401-426. [CrossRef] [PubMed]

84. Yusif, S.; Hafeez-Baig, A.; Soar, J. e-Health readiness assessment factors and measuring tools: A systematic review. Int. J. Med. Inform. 2017, 107, 56-64. [CrossRef]

85. Logan, A.G.; Jassal, S.V. Building a Stronger Care Loop Through mHealth Technology. JAMA Intern. Med. 2018, 178, 809-811. [CrossRef]

86. McLean, S.; Sheikh, A.; Cresswell, K.; Nurmatov, U.; Mukherjee, M.; Hemmi, A.; Pagliari, C. The impact of telehealthcare on the quality and safety of care: A systematic overview. PLoS ONE 2013, 8, e71238. [CrossRef]

87. Stinson, J.; McGrath, P.; Hodnett, E.; Feldman, B.; Duffy, C.; Huber, A.; Tucker, L.; Hetherington, R.; Tse, S.; Spiegel, L.; et al. Usability testing of an online self-management program for adolescents with juvenile idiopathic arthritis. J. Med. Internet Res. 2010, 12, e30. [CrossRef]

88. Zomer-Kooijker, K.; van Erp, F.C.; Balemans, W.A.; van Ewijk, B.E.; van der Ent, C.K. The expert network and electronic portal for children with respiratory and allergic symptoms: Rationale and design. BMC Pediatr. 2013, 13, 9. [CrossRef] [PubMed]

89. HealthIT.gov. What Is a Patient Portal? Available online: https:/www.healthit.gov/providers-professionals/ faqs/what-patient-portal (accessed on 5 November 2018).

90. Kruse, C.S.; Bolton, K.; Freriks, G. The effect of patient portals on quality outcomes and its implications to meaningful use: A systematic review. J. Med. Internet Res. 2015, 17, e44. [CrossRef]

91. Redelmeier, D.A.; Kraus, N.C. Patterns in Patient Access and Utilization of Online Medical Records: Analysis of MyChart. J. Med. Internet Res. 2018, 20, e43. [CrossRef] 
92. CMS. Eligible Professional EHR Incentive Program Objectives and Measures for 2016. Objective 9 of 10. Available online: https:/www.cms.gov/Regulations-and-Guidance/Legislation/EHRIncentivePrograms/ Downloads/2016EP_9SecureElectronicMessagingObjective.pdf (accessed on 3 November 2018).

93. North, F.; Crane, S.J.; Stroebel, R.J.; Cha, S.S.; Edell, E.S.; Tulledge-Scheitel, S.M. Patient-generated secure messages and eVisits on a patient portal: Are patients at risk? J. Am. Med. Inform. Assoc. JAMIA 2013, 20, 1143-1149. [CrossRef] [PubMed]

94. Joshi, S. HIPAA, HIPAA, Hooray?: Current Challenges and Initiatives in Health Informatics in the United States. Biomed. Inform. Insights 2008, 1, 45-54. [CrossRef] [PubMed]

95. Masterman, M.; Cronin, R.M.; Davis, S.E.; Shenson, J.A.; Jackson, G.P. Adoption of Secure Messaging in a Patient Portal across Pediatric Specialties. AMIA Annu. Symp. Proc. 2016, 2016, 1930-1939.

96. De Lusignan, S.; Mold, F.; Sheikh, A.; Majeed, A.; Wyatt, J.C.; Quinn, T.; Cavill, M.; Gronlund, T.A.; Franco, C.; Chauhan, U.; et al. Patients' online access to their electronic health records and linked online services: A systematic interpretative review. BMJ Open 2014, 4, e006021. [CrossRef]

97. Wallwiener, M.; Wallwiener, C.W.; Kansy, J.K.; Seeger, H.; Rajab, T.K. Impact of electronic messaging on the patient-physician interaction. J. Telemed. Telecare 2009, 15, 243-250. [CrossRef]

98. Cronin, R.M.; Fabbri, D.; Denny, J.C.; Rosenbloom, S.T.; Jackson, G.P. A comparison of rule-based and machine learning approaches for classifying patient portal messages. Int. J. Med. Inform. 2017, 105, 110-120. [CrossRef]

99. Deshpande, P.R.; Rajan, S.; Sudeepthi, B.L.; Abdul Nazir, C.P. Patient-reported outcomes: A new era in clinical research. Perspect. Clin. Res. 2011, 2, 137-144. [CrossRef]

100. Wheat, H.; Horrell, J.; Valderas, J.M.; Close, J.; Fosh, B.; Lloyd, H. Can practitioners use patient reported measures to enhance person centred coordinated care in practice? A qualitative study. Health Qual. Life Outcomes 2018, 16, 223. [CrossRef]

101. Vaida, B. Patient-Centered Outcomes Research: Early Evidence from A Burgeoning Field. Health Aff. 2016, 35, 595-602. [CrossRef] [PubMed]

102. Jensen, R.E.; Potosky, A.L.; Moinpour, C.M.; Lobo, T.; Cella, D.; Hahn, E.A.; Thissen, D.; Smith, A.W.; Ahn, J.; Luta, G.; et al. United States Population-Based Estimates of Patient-Reported Outcomes Measurement Information System Symptom and Functional Status Reference Values for Individuals with Cancer. J. Clin. Oncol. 2017, 35, 1913-1920. [CrossRef]

103. Walter, H.; Sadeque-Iqbal, F.; Ulysse, R.; Castillo, D.; Fitzpatrick, A.; Singleton, J. Effectiveness of school-based family asthma educational programs in quality of life and asthma exacerbations in asthmatic children aged five to 18: A systematic review. JBI Database Syst. Rev. Implement. Rep. 2016, 14, 113-138. [CrossRef]

104. Broderick, J.E.; DeWitt, E.M.; Rothrock, N.; Crane, P.K.; Forrest, C.B. Advances in Patient-Reported Outcomes: The NIH PROMIS((R)) Measures. Egems 2013, 1, 1015. [CrossRef] [PubMed]

105. Basch, E. Patient-Reported Outcomes-Harnessing Patients' Voices to Improve Clinical Care. N. Engl. J. Med. 2017, 376, 105-108. [CrossRef]

106. Lloyd, H.; Wheat, H.; Horrell, J.; Sugavanam, T.; Fosh, B.; Valderas, J.M.; Close, J. Patient-Reported Measures for Person-Centered Coordinated Care: A Comparative Domain Map and Web-Based Compendium for Supporting Policy Development and Implementation. J. Med. Internet Res. 2018, 20, e54. [CrossRef] [PubMed]

107. Jensen, R.E.; Rothrock, N.E.; DeWitt, E.M.; Spiegel, B.; Tucker, C.A.; Crane, H.M.; Forrest, C.B.; Patrick, D.L.; Fredericksen, R.; Shulman, L.M.; et al. The role of technical advances in the adoption and integration of patient-reported outcomes in clinical care. Med. Care 2015, 53, 153-159. [CrossRef]

108. Norquist, J.; Chirovsky, D.; Munshi, T.; Tolley, C.; Panter, C.; Gater, A. Assessing the Comparability of Paper and Electronic Versions of the EORTC QOL Module for Head and Neck Cancer: A Qualitative Study. JMIR Cancer 2017, 3, e7. [CrossRef]

109. Mulhern, B.; O'Gorman, H.; Rotherham, N.; Brazier, J. Comparing the measurement equivalence of EQ-5D-5L across different modes of administration. Health Qual. Life Outcomes 2015, 13, 191. [CrossRef] [PubMed]

110. Campbell, N.; Ali, F.; Finlay, A.Y.; Salek, S.S. Equivalence of electronic and paper-based patient-reported outcome measures. Qual. Life Res. 2015, 24, 1949-1961. [CrossRef] [PubMed]

111. Hjollund, N.H.; Larsen, L.P.; Biering, K.; Johnsen, S.P.; Riiskjaer, E.; Schougaard, L.M. Use of Patient-Reported Outcome (PRO) Measures at Group and Patient Levels: Experiences From the Generic Integrated PRO System, WestChronic. Interact. J. Med. Res. 2014, 3, e5. [CrossRef] [PubMed] 
112. Moura, L.M.; Schwamm, E.; Moura Junior, V.; Seitz, M.P.; Hsu, J.; Cole, A.J.; Schwamm, L.H. Feasibility of the collection of patient-reported outcomes in an ambulatory neurology clinic. Neurology 2016, 87, 2435-2442. [CrossRef]

113. Warrington, L.; Absolom, K.; Conner, M.; Kellar, I.; Clayton, B.; Ayres, M.; Velikova, G. Electronic Systems for Patients to Report and Manage Side Effects of Cancer Treatment: Systematic Review. J. Med. Internet Res. 2019, 21, e10875. [CrossRef]

114. Kelly, A.; Rush, J.; Shafonsky, E.; Hayashi, A.; Votova, K.; Hall, C.; Piccinin, A.M.; Weber, J.; Rast, P.; Hofer, S.M. Detecting short-term change and variation in health-related quality of life: Within- and between-person factor structure of the SF-36 health survey. Health Qual. Life Outcomes 2015, 13, 199. [CrossRef]

115. Ahmed, S.; Ernst, P.; Bartlett, S.J.; Valois, M.F.; Zaihra, T.; Pare, G.; Grad, R.; Eilayyan, O.; Perreault, R.; Tamblyn, R. The Effectiveness of Web-Based Asthma Self-Management System, My Asthma Portal (MAP): A Pilot Randomized Controlled Trial. J. Med. Internet Res. 2016, 18, e313. [CrossRef] [PubMed]

116. Gondek, D.; Edbrooke-Childs, J.; Fink, E.; Deighton, J.; Wolpert, M. Feedback from Outcome Measures and Treatment Effectiveness, Treatment Efficiency, and Collaborative Practice: A Systematic Review. Adm. Policy Ment. Health 2016, 43, 325-343. [CrossRef]

117. Donaldson, M.S. Taking PROs and patient-centered care seriously: Incremental and disruptive ideas for incorporating PROs in oncology practice. Qual. Life Res. 2008, 17, 1323-1330. [CrossRef] [PubMed]

118. Hartkopf, A.D.; Graf, J.; Simoes, E.; Keilmann, L.; Sickenberger, N.; Gass, P.; Wallwiener, D.; Matthies, L.; Taran, F.A.; Lux, M.P.; et al. Electronic-Based Patient-Reported Outcomes: Willingness, Needs, and Barriers in Adjuvant and Metastatic Breast Cancer Patients. JMIR Cancer 2017, 3, e11. [CrossRef] [PubMed]

119. Black, A.D.; Car, J.; Pagliari, C.; Anandan, C.; Cresswell, K.; Bokun, T.; McKinstry, B.; Procter, R.; Majeed, A.; Sheikh, A. The impact of eHealth on the quality and safety of health care: A systematic overview. PLoS Med. 2011, 8, e1000387. [CrossRef]

120. Steele Gray, C.; Gill, A.; Khan, A.I.; Hans, P.K.; Kuluski, K.; Cott, C. The Electronic Patient Reported Outcome Tool: Testing Usability and Feasibility of a Mobile App and Portal to Support Care for Patients With Complex Chronic Disease and Disability in Primary Care Settings. JMIR mHealth uHealth 2016, 4, e58. [CrossRef] [PubMed]

121. Schwartzberg, L. Electronic Patient-Reported Outcomes: The Time Is Ripe for Integration Into Patient Care and Clinical Research. Am. Soc. Clin. Oncol. Educ. Book. 2016, 35, e89-e96. [CrossRef] [PubMed]

122. Basch, E.; Goldfarb, S. Electronic patient-reported outcomes for collecting sensitive information from patients. J. Support. Oncol. 2009, 7, 98-99.

123. Valderas, J.M.; Kotzeva, A.; Espallargues, M.; Guyatt, G.; Ferrans, C.E.; Halyard, M.Y.; Revicki, D.A.; Symonds, T.; Parada, A.; Alonso, J. The impact of measuring patient-reported outcomes in clinical practice: A systematic review of the literature. Qual. Life Res. 2008, 17, 179-193. [CrossRef] [PubMed]

124. Marshall, S.; Haywood, K.; Fitzpatrick, R. Impact of patient-reported outcome measures on routine practice: A structured review. J. Eval. Clin. Pract. 2006, 12, 559-568. [CrossRef]

125. Greenhalgh, J.; Meadows, K. The effectiveness of the use of patient-based measures of health in routine practice in improving the process and outcomes of patient care: A literature review. J. Eval. Clin. Pract. 1999, 5, 401-416. [CrossRef]

126. Murillo, M.; Bel, J.; Perez, J.; Corripio, R.; Carreras, G.; Herrero, X.; Mengibar, J.M.; Rodriguez-Arjona, D.; Ravens-Sieberer, U.; Raat, H.; et al. Impact of monitoring health-related quality of life in clinical practice in children with type 1 diabetes mellitus. Qual. Life Res. 2017, 26, 3267-3277. [CrossRef] [PubMed]

127. Tjaden, L.A.; Grootenhuis, M.A.; Noordzij, M.; Groothoff, J.W. Health-related quality of life in patients with pediatric onset of end-stage renal disease: State of the art and recommendations for clinical practice. Pediatr. Nephrol. 2016, 31, 1579-1591. [CrossRef] [PubMed]

128. Verhoof, E.J.; Maurice-Stam, H.; Heymans, H.S.; Evers, A.W.; Grootenhuis, M.A. Psychosocial well-being in young adults with chronic illness since childhood: The role of illness cognitions. Child Adolesc. Psychiatry Ment. Health 2014, 8, 12. [CrossRef]

129. Haverman, L.; Engelen, V.; van Rossum, M.A.; Heymans, H.S.; Grootenhuis, M.A. Monitoring health-related quality of life in paediatric practice: Development of an innovative web-based application. BMC Pediatr. 2011, 11, 3. [CrossRef] [PubMed]

130. Snyder, C.F.; Jensen, R.; Courtin, S.O.; Wu, A.W. PatientViewpoint: A website for patient-reported outcomes assessment. Qual. Life Res. 2009, 18, 793-800. [CrossRef] [PubMed] 
131. King, S.; Exley, J.; Parks, S.; Ball, S.; Bienkowska-Gibbs, T.; MacLure, C.; Harte, E.; Stewart, K.; Larkin, J.; Bottomley, A.; et al. The use and impact of quality of life assessment tools in clinical care settings for cancer patients, with a particular emphasis on brain cancer: Insights from a systematic review and stakeholder consultations. Qual. Life Res. 2016, 25, 2245-2256. [CrossRef] [PubMed]

132. Basch, E.; Deal, A.M.; Kris, M.G.; Scher, H.I.; Hudis, C.A.; Sabbatini, P.; Rogak, L.; Bennett, A.V.; Dueck, A.C.; Atkinson, T.M.; et al. Symptom Monitoring With Patient-Reported Outcomes During Routine Cancer Treatment: A Randomized Controlled Trial. J. Clin. Oncol. 2016, 34, 557-565. [CrossRef] [PubMed]

133. Velikova, G.; Booth, L.; Smith, A.B.; Brown, P.M.; Lynch, P.; Brown, J.M.; Selby, P.J. Measuring quality of life in routine oncology practice improves communication and patient well-being: A randomized controlled trial. J. Clin. Oncol. 2004, 22, 714-724. [CrossRef] [PubMed]

134. Petersson, C.; Simeonsson, R.J.; Enskar, K.; Huus, K. Comparing children's self-report instruments for health-related quality of life using the International Classification of Functioning, Disability and Health for Children and Youth (ICF-CY). Health Qual. Life Outcomes 2013, 11, 75. [CrossRef] [PubMed]

135. Emery, M.P.; Perrier, L.L.; Acquadro, C. Patient-reported outcome and quality of life instruments database (PROQOLID): Frequently asked questions. Health Qual. Life Outcomes 2005, 3, 12. [CrossRef] [PubMed]

136. Rothman, M.; Burke, L.; Erickson, P.; Leidy, N.K.; Patrick, D.L.; Petrie, C.D. Use of existing patient-reported outcome (PRO) instruments and their modification: The ISPOR Good Research Practices for Evaluating and Documenting Content Validity for the Use of Existing Instruments and Their Modification PRO Task Force Report. Value Health 2009, 12, 1075-1083. [CrossRef]

137. National Heart, Lung, and Blood Institute. National Asthma Education and Prevention Program, Guidelines for the Diagnosis and Management of Asthma; U.S. Department of Health and Human Services: Bethesda, MD, USA, 2007; Volume 3, p. 1007.

138. Voorend-van Bergen, S.; Vaessen-Verberne, A.A.; Landstra, A.M.; Brackel, H.J.; van den Berg, N.J.; Caudri, D.; de Jongste, J.C.; Merkus, P.J.; Pijnenburg, M.W. Monitoring childhood asthma: Web-based diaries and the asthma control test. J. Allergy Clin. Immunol. 2014, 133, 1599-1605. [CrossRef]

139. Rhee, H.; Fairbanks, E.; Butz, A. Symptoms, feelings, activities and medication use in adolescents with uncontrolled asthma: Lessons learned from asthma diaries. J. Pediatr. Nurs. 2014, 29, 39-46. [CrossRef] [PubMed]

140. Kupczyk, M.; Haque, S.; Sterk, P.J.; Nizankowska-Mogilnicka, E.; Papi, A.; Bel, E.H.; Chanez, P.; Dahlen, B.; Gaga, M.; Gjomarkaj, M.; et al. Detection of exacerbations in asthma based on electronic diary data: Results from the 1-year prospective BIOAIR study. Thorax 2013, 68, 611-618. [CrossRef]

141. Jiang, H.; Han, J.; Zhu, Z.; Xu, W.; Zheng, J.; Zhu, Y. Patient compliance with assessing and monitoring of asthma. J. Asthma 2009, 46, 1027-1031. [CrossRef]

142. Meltzer, E.O.; Kelley, N.; Hovell, M.F. Randomized, cross-over evaluation of mobile phone vs paper diary in subjects with mild to moderate persistent asthma. Open Respir. Med. J. 2008, 2, 72-79. [CrossRef] [PubMed]

143. Shapiro, M.; Johnston, D.; Wald, J.; Mon, D. Patient-generated Health Data: White Paper Prepared for the Office of the National Coordinator for Health it by RTI International. Available online: http: //www.rti.org/pubs/patientgeneratedhealthdata.pdf (accessed on 10 October 2017).

144. Wood, W.A.; Bennett, A.V.; Basch, E. Emerging uses of patient generated health data in clinical research. Mol. Oncol. 2015, 9, 1018-1024. [CrossRef] [PubMed]

145. Petersen, C.; DeMuro, P. Legal and regulatory considerations associated with use of patient-generated health data from social media and mobile health (mHealth) devices. Appl. Clin. Inform. 2015, 6, 16-26. [CrossRef]

146. Chung, C.F.; Dew, K.; Cole, A.; Zia, J.; Fogarty, J.; Kientz, J.A.; Munson, S.A. Boundary Negotiating Artifacts in Personal Informatics: Patient-Provider Collaboration with Patient-Generated Data. In Proceedings of the 19th ACM Conference on Computer-Supported Cooperative Work \& Social Computing, San Francisco, CA, USA, 27 February-2 March 2016; Volume 2016, pp. 770-786. [CrossRef]

147. White, R.W.; Harpaz, R.; Shah, N.H.; DuMouchel, W.; Horvitz, E. Toward enhanced pharmacovigilance using patient-generated data on the internet. Clin. Pharmacol. Ther. 2014, 96, 239-246. [CrossRef]

148. Arend, J.; Tsang-Quinn, J.; Levine, C.; Thomas, D. The patient-centered medical home: History, components, and review of the evidence. Mt. Sinai J. Med. 2012, 79, 433-450. [CrossRef]

149. Sia, C.; Tonniges, T.F.; Osterhus, E.; Taba, S. History of the medical home concept. Pediatrics 2004, 113, 1473-1478.

150. Mittal, V. Family-centered rounds. Pediatr. Clin. North. Am. 2014, 61, 663-670. [CrossRef] [PubMed] 
151. Richardson, J.E.; Vest, J.R.; Green, C.M.; Kern, L.M.; Kaushal, R. A needs assessment of health information technology for improving care coordination in three leading patient-centered medical homes. J. Am. Med. Inform. Assoc. JAMIA 2015, 22, 815-820. [CrossRef] [PubMed]

152. Morton, S.; Shih, S.C.; Winther, C.H.; Tinoco, A.; Kessler, R.S.; Scholle, S.H. Health IT-Enabled Care Coordination: A National Survey of Patient-Centered Medical Home Clinicians. Ann. Fam. Med. 2015, 13, 250-256. [CrossRef] [PubMed]

153. Tschudy, M.M.; Raphael, J.L.; Nehal, U.S.; O'Connor, K.G.; Kowalkowski, M.; Stille, C.J. Barriers to Care Coordination and Medical Home Implementation. Pediatrics 2016, 138, e20153458. [CrossRef] [PubMed]

154. Auschra, C. Barriers to the Integration of Care in Inter-Organisational Settings: A Literature Review. Int. J. Integr. Care 2018, 18, 5. [CrossRef]

155. Ferrer, L.; Goodwin, N. What are the principles that underpin integrated care? Int. J. Integr. Care 2014, 14, e037. [CrossRef]

156. Hardy, B.; Mur-Veemanu, I.; Steenbergen, M.; Wistow, G. Inter-agency services in England and The Netherlands. A comparative study of integrated care development and delivery. Health Policy 1999, 48, 87-105. [CrossRef]

157. Ling, T.; Brereton, L.; Conklin, A.; Newbould, J.; Roland, M. Barriers and facilitators to integrating care: Experiences from the English Integrated Care Pilots. Int. J. Integr. Care 2012, 12, e129. [CrossRef] [PubMed]

158. Orzol, S.; Keith, R.; Hossain, M.; Barna, M.; Peterson, G.G.; Day, T.; Gilman, B.; Blue, L.; Kranker, K.; Stewart, K.A.; et al. The Impact of a Health Information Technology-Focused Patient-centered Medical Neighborhood Program Among Medicare Beneficiaries in Primary Care Practices: The Effect on Patient Outcomes and Spending. Med. Care 2018, 56, 299-307. [CrossRef] [PubMed]

159. Spatz, C.; Bricker, P.; Gabbay, R. The Patient-Centered Medical Neighborhood: Transformation of Specialty Care. Am. J. Med. Qual. 2014, 29, 344-349. [CrossRef]

160. Greenberg, J.O.; Barnett, M.L.; Spinks, M.A.; Dudley, J.C.; Frolkis, J.P. The "medical neighborhood": Integrating primary and specialty care for ambulatory patients. JAMA Intern. Med. 2014, 174, 454-457. [CrossRef] [PubMed]

161. Feuerstein, J.D.; Sheppard, V.; Cheifetz, A.S.; Ariyabuddhiphongs, K. How to Develop the Medical Neighborhood. J. Med. Syst. 2016, 40, 196. [CrossRef]

162. Pordes, E.; Gordon, J.; Sanders, L.M.; Cohen, E. Models of Care Delivery for Children With Medical Complexity. Pediatrics 2018, 141, S212-S223. [CrossRef]

163. The American College of Physicians. The Patient-Centered Medical Home Neighbor: The Interface of the Patient-Centered Medical Home with Specialty/Subspecialty Practices. Available online: http://www. acponline.org.ezp-prod1.hul.harvard.edu/advocacy/where_we_stand/policy/pcmh_neighbors.pdf (accessed on 25 May 2018).

164. Rittenhouse, D.R.; Casalino, L.P.; Shortell, S.M.; McClellan, S.R.; Gillies, R.R.; Alexander, J.A.; Drum, M.L. Small and medium-size physician practices use few patient-centered medical home processes. Health Aff. 2011, 30, 1575-1584. [CrossRef]

165. Rittenhouse, D.R.; Shortell, S.M.; Gillies, R.R.; Casalino, L.P.; Robinson, J.C.; McCurdy, R.K.; Siddique, J. Improving chronic illness care: Findings from a national study of care management processes in large physician practices. Med. Care Res. Rev. MCRR 2010, 67, 301-320. [CrossRef]

166. Singer, S.J.; Burgers, J.; Friedberg, M.; Rosenthal, M.B.; Leape, L.; Schneider, E. Defining and measuring integrated patient care: Promoting the next frontier in health care delivery. Med. Care Res. Rev. MCRR 2011, 68, 112-127. [CrossRef]

167. Rodriguez, H.P.; Henke, R.M.; Bibi, S.; Ramsay, P.P.; Shortell, S.M. The Exnovation of Chronic Care Management Processes by Physician Organizations. Milbank Q. 2016, 94, 626-653. [CrossRef]

168. Venkatesh, V.; Morris, M.G.; Davis, G.B.; Davis, F.D. User acceptance of information technology: Toward a unified view. MIS Q. 2003, 27, 157-178. [CrossRef]

169. Roberts, N.; Bradley, B.; Williams, D. Use of SMS and tablet computer improves the electronic collection of elective orthopaedic patient reported outcome measures. Ann. R. Coll. Surg. Engl. 2014, 96, 348-351. [CrossRef]

170. Wolpert, M.; Curtis-Tyler, K.; Edbrooke-Childs, J. A Qualitative Exploration of Patient and Clinician Views on Patient Reported Outcome Measures in Child Mental Health and Diabetes Services. Adm. Policy Ment. Health 2016, 43, 309-315. [CrossRef] [PubMed] 
171. Wolfe, J.; Orellana, L.; Cook, E.F.; Ullrich, C.; Kang, T.; Geyer, J.R.; Feudtner, C.; Weeks, J.C.; Dussel, V. Improving the care of children with advanced cancer by using an electronic patient-reported feedback intervention: Results from the PediQUEST randomized controlled trial. J. Clin. Oncol. 2014, 32, 1119-1126. [CrossRef]

172. Snyder, C.F.; Herman, J.M.; White, S.M.; Luber, B.S.; Blackford, A.L.; Carducci, M.A.; Wu, A.W. When using patient-reported outcomes in clinical practice, the measure matters: A randomized controlled trial. J. Oncol. Pract. 2014, 10, e299-e306. [CrossRef]

173. Van der Wall, E.E. E-Health: A novel way to redesigning healthcare. Neth. Heart J. 2016, 24, 439-440. [CrossRef]

174. Atreja, A.; Otobo, E.; Ramireddy, K.; Deorocki, A. Remote Patient Monitoring in IBD: Current State and Future Directions. Curr. Gastroenterol. Rep. 2018, 20, 6. [CrossRef] [PubMed]

175. Rosner, M.H.; Lew, S.Q.; Conway, P.; Ehrlich, J.; Jarrin, R.; Patel, U.D.; Rheuban, K.; Robey, R.B.; Sikka, N.; Wallace, E.; et al. Perspectives from the Kidney Health Initiative on Advancing Technologies to Facilitate Remote Monitoring of Patient Self-Care in RRT. Clin. J. Am. Soc. Nephrol. CJASN 2017, 12, 1900-1909. [CrossRef]

176. Hargreaves, S.; Hawley, M.S.; Haywood, A.; Enderby, P.M. Informing the Design of "Lifestyle Monitoring" Technology for the Detection of Health Deterioration in Long-Term Conditions: A Qualitative Study of People Living With Heart Failure. J. Med. Internet Res. 2017, 19, e231. [CrossRef]

177. Rich, M.W.; Vinson, J.M.; Sperry, J.C.; Shah, A.S.; Spinner, L.R.; Chung, M.K.; Davila-Roman, V. Prevention of readmission in elderly patients with congestive heart failure: Results of a prospective, randomized pilot study. J. Gen. Intern. Med. 1993, 8, 585-590. [CrossRef]

178. Wan, T.T.H.; Terry, A.; Cobb, E.; McKee, B.; Tregerman, R.; Barbaro, S.D.S. Strategies to Modify the Risk of Heart Failure Readmission: A Systematic Review and Meta-Analysis. Health Serv. Res. Manag. Epidemiol. 2017, 4, 2333392817701050. [CrossRef] [PubMed]

179. He, T.; Liu, X.; Li, Y.; Wu, Q.; Liu, M.; Yuan, H. Remote home management for chronic kidney disease: A systematic review. J. Telemed. Telecare 2017, 23, 3-13. [CrossRef]

180. Klersy, C.; De Silvestri, A.; Gabutti, G.; Raisaro, A.; Curti, M.; Regoli, F.; Auricchio, A. Economic impact of remote patient monitoring: An integrated economic model derived from a meta-analysis of randomized controlled trials in heart failure. Eur. J. Heart Fail. 2011, 13, 450-459. [CrossRef] [PubMed]

181. Inglis, S.C.; Clark, R.A.; Dierckx, R.; Prieto-Merino, D.; Cleland, J.G. Structured telephone support or non-invasive telemonitoring for patients with heart failure. Cochrane Database Syst. Rev. 2015, 10, CD007228. [CrossRef]

182. Clark, R.A. Telehealth in the Elderly with Chronic Heart Failure: What Is the Evidence? Stud. Health Technol. Inform. 2018, 246, 18-23.

183. Schougaard, L.M.; Larsen, L.P.; Jessen, A.; Sidenius, P.; Dorflinger, L.; de Thurah, A.; Hjollund, N.H. AmbuFlex: Tele-patient-reported outcomes (telePRO) as the basis for follow-up in chronic and malignant diseases. Qual. Life Res. 2016, 25, 525-534. [CrossRef] [PubMed]

184. Blumenthal, K.J.; Chang, Y.; Ferris, T.G.; Spirt, J.C.; Vogeli, C.; Wagle, N.; Metlay, J.P. Using a Self-Reported Global Health Measure to Identify Patients at High Risk for Future Healthcare Utilization. J. Gen. Intern. Med. 2017, 32, 877-882. [CrossRef]

185. Basch, E.; Abernethy, A.P. Supporting clinical practice decisions with real-time patient-reported outcomes. J. Clin. Oncol. 2011, 29, 954-956. [CrossRef]

186. Snyder, C.F. Using patient-reported outcomes in clinical practice: A promising approach? J. Clin. Oncol. 2014, 32, 1099-1100. [CrossRef] [PubMed]

187. Griffiths, F.; Bryce, C.; Cave, J.; Dritsaki, M.; Fraser, J.; Hamilton, K.; Huxley, C.; Ignatowicz, A.; Kim, S.W.; Kimani, P.K.; et al. Timely Digital Patient-Clinician Communication in Specialist Clinical Services for Young People: A Mixed-Methods Study (The LYNC Study). J. Med. Internet Res. 2017, 19, e102. [CrossRef]

188. Fredericksen, R.J.; Tufano, J.; Ralston, J.; McReynolds, J.; Stewart, M.; Lober, W.B.; Mayer, K.H.; Mathews, W.C.; Mugavero, M.J.; Crane, P.K.; et al. Provider perceptions of the value of same-day, electronic patient-reported measures for use in clinical HIV care. AIDS Care 2016, 28, 1428-1433. [CrossRef]

189. Snyder, C.F.; Blackford, A.L.; Wolff, A.C.; Carducci, M.A.; Herman, J.M.; Wu, A.W. Feasibility and value of PatientViewpoint: A web system for patient-reported outcomes assessment in clinical practice. Psycho-Oncol. 2013, 22, 895-901. [CrossRef] 
190. Johansen, M.A.; Berntsen, G.K.; Schuster, T.; Henriksen, E.; Horsch, A. Electronic symptom reporting between patient and provider for improved health care service quality: A systematic review of randomized controlled trials. part 2: Methodological quality and effects. J. Med. Internet Res. 2012, 14, e126. [CrossRef]

191. Fairbrother, P.; Ure, J.; Hanley, J.; McCloughan, L.; Denvir, M.; Sheikh, A.; McKinstry, B. Telemonitoring for chronic heart failure: The views of patients and healthcare professionals-A qualitative study. J. Clin. Nurs. 2014, 23, 132-144. [CrossRef]

192. Kirsch, F. Economic Evaluations of Multicomponent Disease Management Programs with Markov Models: A Systematic Review. Value Health 2016, 19, 1039-1054. [CrossRef]

193. Pollettini, J.T.; Panico, S.R.; Daneluzzi, J.C.; Tinos, R.; Baranauskas, J.A.; Macedo, A.A. Using machine learning classifiers to assist healthcare-related decisions: Classification of electronic patient records. J. Med. Syst. 2012, 36, 3861-3874. [CrossRef] [PubMed]

194. Ramgopal, S.; Thome-Souza, S.; Jackson, M.; Kadish, N.E.; Sanchez Fernandez, I.; Klehm, J.; Bosl, W.; Reinsberger, C.; Schachter, S.; Loddenkemper, T. Seizure detection, seizure prediction, and closed-loop warning systems in epilepsy. Epilepsy Behav. 2014, 37, 291-307. [CrossRef] [PubMed]

195. Hazara, A.M.; Elgaali, M.; Naudeer, S.; Holding, S.; Bhandari, S. The Use of Automated Electronic Alerts in Studying Short-Term Outcomes Associated with Community-Acquired Acute Kidney Injury. Nephron 2017, 135, 181-188. [CrossRef] [PubMed]

196. Lachance, P.; Villeneuve, P.M.; Wilson, F.P.; Selby, N.M.; Featherstone, R.; Rewa, O.; Bagshaw, S.M. Impact of e-alert for detection of acute kidney injury on processes of care and outcomes: Protocol for a systematic review and meta-analysis. BMJ Open 2016, 6, e011152. [CrossRef] [PubMed]

197. Wilson, F.P. Information Technology and Acute Kidney Injury: Alerts, Alarms, Bells, and Whistles. Adv. Chronic Kidney Dis. 2017, 24, 241-245. [CrossRef]

198. Lai, J.S.; Yount, S.; Beaumont, J.L.; Cella, D.; Toia, J.; Goldman, S. A patient-centered symptom monitoring and reporting system for children and young adults with cancer (SyMon-SAYS). Pediatr. Blood Cancer 2015, 62, 1813-1818. [CrossRef] [PubMed]

199. Flodgren, G.; Rachas, A.; Farmer, A.J.; Inzitari, M.; Shepperd, S. Interactive telemedicine: Effects on professional practice and health care outcomes. Cochrane Database Syst. Rev. 2015, 9, CD002098. [CrossRef] [PubMed]

200. Breen, S.; Ritchie, D.; Schofield, P.; Hsueh, Y.S.; Gough, K.; Santamaria, N.; Kamateros, R.; Maguire, R.; Kearney, N.; Aranda, S. The Patient Remote Intervention and Symptom Management System (PRISMS)—A Telehealth-mediated intervention enabling real-time monitoring of chemotherapy side-effects in patients with haematological malignancies: Study protocol for a randomised controlled trial. Trials 2015, 16, 472. [CrossRef]

201. Cox, A.; Lucas, G.; Marcu, A.; Piano, M.; Grosvenor, W.; Mold, F.; Maguire, R.; Ream, E. Cancer Survivors' Experience With Telehealth: A Systematic Review and Thematic Synthesis. J. Med. Internet Res. 2017, 19 , e11. [CrossRef] [PubMed]

202. Siddique, S.M.; Mehta, S.J. Market Evaluation: Finances, Bundled Payments, and Accountable Care Organizations. Anesthesiol. Clin. 2017, 35, 715-724. [CrossRef]

203. Darves-Bornoz, A.L.; Resnick, M.J. The evolution of financial incentives in the U.S. health care system. Urol. Oncol. 2017, 35, 1-4. [CrossRef] [PubMed]

204. Bull, T.P.; Dewar, A.R.; Malvey, D.M.; Szalma, J.L. Considerations for the Telehealth Systems of Tomorrow: An Analysis of Student Perceptions of Telehealth Technologies. JMIR Med. Educ. 2016, 2, e11. [CrossRef] [PubMed]

205. Milani, R.V.; Bober, R.M.; Lavie, C.J. The Role of Technology in Chronic Disease Care. Prog. Cardiovasc. Dis. 2016, 58, 579-583. [CrossRef] [PubMed]

206. Boudioni, M.; McLaren, S.; Lister, G. A critical analysis of national policies, systems, and structures of patient empowerment in England and Greece. Patient Prefer. Adherence 2017, 11, 1657-1669. [CrossRef]

207. Chen, Y.; Yang, L.; Hu, H.; Chen, J.; Shen, B. How to Become a Smart Patient in the Era of Precision Medicine? Adv. Exp. Med. Biol. 2017, 1028, 1-16. [CrossRef]

208. Risling, T.; Martinez, J.; Young, J.; Thorp-Froslie, N. Evaluating Patient Empowerment in Association With eHealth Technology: Scoping Review. J. Med. Internet Res. 2017, 19, e329. [CrossRef]

209. Hynek, P. The Hyper-Commons: How open science prizes can expand and level the medical research playing field. Rejuv. Res. 2008, 11, 1065-1072. [CrossRef] [PubMed] 
210. Friend, S.H.; Norman, T.C. Metcalfe's law and the biology information commons. Nat. Biotechnol. 2013, 31, 297-303. [CrossRef]

211. Mandl, K.D.; Kohane, I.S.; McFadden, D.; Weber, G.M.; Natter, M.; Mandel, J.; Schneeweiss, S.; Weiler, S.; Klann, J.G.; Bickel, J.; et al. Scalable Collaborative Infrastructure for a Learning Healthcare System (SCILHS): Architecture. J. Am. Med. Inform. Assoc. JAMIA 2014, 21, 615-620. [CrossRef] [PubMed]

212. Ruley, M.; Walker, V.; Studeny, J.; Coustasse, A. The Nationwide Health Information Network: The Case of the Expansion of Health Information Exchanges in the United States. Health Care Manag. 2018, 37, 333-338. [CrossRef] [PubMed]

(C) 2019 by the authors. Licensee MDPI, Basel, Switzerland. This article is an open access article distributed under the terms and conditions of the Creative Commons Attribution (CC BY) license (http://creativecommons.org/licenses/by/4.0/). 